\title{
Water and Coastal Water Vegetation of Various Types of Waters in the Samarkand Region
}

\author{
Y.Sh. Tashpulatov ${ }^{*}$, I.Kh. Khamdamov ${ }^{2}$ and A.A. Nurniyozov ${ }^{2}$ \\ ${ }^{1}$ Samarkand State University, Samarkand, Uzbekistan \\ ${ }^{2}$ Samarkand Institute of Veterinary Medicine, Samarkand, Uzbekistan
}

*Corresponding author

\section{A B S T R A C T}

Keywords

Aquatic plant, Growth,

Formation,

Association, Longline,

Herbage, Flood plants,

Hydrophyte

Article Info

Accepted:

10 July 2019

Available Online:

10 August 2019
In the study of hydrobiology of water basins, a separate study of higher plants is required. Higher plants growing in water for aquatic organisms remain not only a habitat, a nutrient, a source of oxygen, but they are also important in the course of many biological processes in this environment. The vegetation of aquatic and coastal aquatic plants weakens the rate of flow of water, impedes the movement of silt and mineral particles, has antierosion significance and is used to strengthen the banks of water bodies. Among the higher aquatic and coastal aquatic plants, many species have diverse uses as a raw material for the pulp and paper, medical, perfume industries, building materials, fertilizers for the fields, food for people and pet food.

\section{Introduction}

Intensive management of water bodies, including their pollution, create the need for continuous monitoring of the state of aquatic ecosystems, one of the key components of which are aquatic plants. Floristic studies of reservoirs and watercourses serve as a basis for studying vegetation, reconstructing the history of flora formation, identifying rare and vulnerable plant species in need of protection, provide information about the anthropogenic transformation of the territory. Reservoirs, watercourses, wetlands are represented by a huge variety of habitat types (ecotops); contain a significant part of the biodiversity of a territory and many rare, relict and species needing protection (Gopal, 2009); affect the biodiversity of the surrounding landscape elements, and in arid conditions are the centers to which most of the biota is tied, especially its animal population: birds, mammals, whose population dynamics depend on the cyclical nature of changes in watercourses and watercourses (Kirilyuk et al., 2012, Kirilyuk et al., 2012). At the same time, the concept of wetlands is inextricably linked with their plant component, without which it is just soil, soil and water (Kadlec, Wallace, 2009). In addition, the 
anthropogenic impact, grazing and introduction of exotic species (advents) affect the biodiversity of wetlands more than other ecosystems.

Currently, much attention is paid to the rational use and development of inland water bodies of the country. Aquatic and coastal aquatic plants are one of the most important components of aquatic ecosystems. Together with phytoplankton, they participate in the trophic cycle, ensuring the production of various parts of the food chain. The plants of the reservoirs serve as food for animals of the most diverse systematic position of mollusks, crustaceans, insects, fish, birds and mammals. With moderate overgrowing of water bodies, favorable conditions are created for the development of the phytophilic invertebrate fauna.

Thickets of aquatic plants in hunting and fish farms are important as nesting and feeding grounds for waterfowl and wading birds and feeding and breeding fish.

In the study of hydrobiology of water basins, a separate study of higher plants is required. Higher plants growing in water for aquatic organisms remain not only a habitat, a nutrient, a source of oxygen, but they are also important in the course of many biological processes in this environment. Most aquatic plants are biological indicators of eutrophication processes in water basins (Kirichenko, 2015). For this, first of all, the study of floristic, taxonomic and ecological features of higher aquatic plants in water basins and the determination of indicators of their productivity is required (Scherbakov, 2015).

The classification of vegetation in water bodies and watercourses should be based on the classification of ecotypes of water plants. It is necessary to use only its aquatic and coastal-aquatic components, since coastal plants entering the water do not form communities under the conditions of watercovered ground. The most relevant to this view is the dominant-determinant approach to the description and identification of types of plant communities (associations) and the use of a dominant classification scheme, the main units of which are associations, formations, formation groups, formation classes, formation class groups and vegetation type.

All associations characterized by a common dominant-edificator (or, more rarely, a pair of common edificators) are combined into one formation. The latter can unite and communities of ecologically similar closely related taxa. One group includes formations in whose communities' edificators belong to the same eco-group of macrophytes. Phytocenoses with edificators of one ecotype are combined into one class of formations. The group of classes of the latter includes communities with edificators of one group of ecotypes.

All syntaxa of the vegetation cover of water bodies and watercourses belong to one type of vegetation, called aquatic (Papchenkov, 2003).

The main purpose of this study the aquatic and coastal aquatic vegetation of different types of water bodies in the region and separate their formations and associations. Determine the constituent components and their number of studied associations.

\section{Materials and Methods}

The study is aimed at the collection of herbarium materials of higher plants from different types of reservoirs (canals, drainage networks, ponds for growing fish, cai, reservoirs, river beds, others) in the 
Samarkand region of Uzbekistan, studying their taxonomy, biological types and their associations. Research work was carried out on the planned route. Samarkand region is located in the middle of the Zarafshan river basin.

The collection and drying of herbarium materials was carried out according to the methods of L.I. Lisitsina (2003). Plants that grow on the water or at the bottom of the water basin were taken by hand, plants that grow a little deep in the water - with the help of hooks of different lengths. In determining the species composition and taxonomic analysis, monographs "The Key to Plants of Central Asia" were used (1968).

A visual assessment of the species composition of plants was conducted. To determine the abundance of species, an eye account was used and the Drude abundance scale was used. The list of plants with abundance marks of species according to Drude is called a qualified list. The volumetric abundance of plants (the degree of filling of the water column with their stems and leaves) means the ratio of the sum of the volumes of spaces occupied by this species to the entire volume of the water column occupied by the community. Volumetric abundance is expressed as a function of coverage and height of vegetation in relation to the area and depth of the biotope (Laktionov et al., 2014).

In our work, we adhered to the principle of classification of vegetation according to physiognomic features (Metody polevyx ekologicheskix issledovaniy, 2014).

For higher aquatic vegetation, the following classification series has been adopted: an association is a formation, a subgroup of formations, a group of formations, a class of formations, a type of vegetation (Papchenkov, 2003).

\section{Results and Discussion}

The flora of higher aquatic plants of the Samarkand region has not yet been fully studied. Species composition was not investigated, taxonomic and floristic analysis was not carried out. In addition, it is very rare to find detailed information about the use in the national economy of the useful species of these plants and about the protected species that are common in this area.

Analysis of few sources shows that the flora of higher wetland plants of the Samarkand region is not fully inventoried, and the taxonomic and bioecological features of the flora have not been analyzed. In addition, the economically valuable species have not been separately investigated. The study of wetland plants, common in different types of waters of the Samarkand region, the definition of the distribution areas of useful and rare species, the development of measures for their protection, a separate study of food species for the areas of fish farming and aquatic animal breeding are the objectives of the study.

Samarkand region is located in the upper part of the Zaravshan river valley and occupies 16.77 thousand $\mathrm{km}^{2}$, which is $3.8 \%$ of the total territory of the Republic of Uzbekistan. The Zaravshan River is the main source of water in the Samarkand region. The Zaravshan River, an ancient tributary of the Amudarya, originates from the Zaravshan Range, feeding on the melt waters of the Zaravshan Glacier.

It flows through the territory of Tajikistan and Uzbekistan. In the north-west of Uzbekistan creates a unique oasis, in the valley of which is located the city of Samarkand. The river originates from the Zaravshansky glacier, located in the intersection of three ridges: Turkestan, Zaravshansky and Altai. Its waters 
are used entirely for national economic needs. In the past, the Zarafshan River was a tributary of the Amu Darya River.

The Zarafshan River is a glacier-snow feed, it is formed by a single confluence of the River Matcha and Fandarya. After leaving the mountains, close to the city of Samarkand, the Zarafshan River splits into two branches: northern Akdarya and southern - Karadarya.

In this regard, in the years 2016-2018, studies were conducted on the study of floristic, taxonomic, ecological and geobotanical features and the economic significance of higher wetland plants that are common in the Taylak, Dzhambay, Bulungur, Samarkand, Ishtikhan, Pastdargomsky and Kattakurgan districts of the Samarkand region.

According to a preliminary taxonomic analysis, it was determined that in the territories where the study was conducted, 75 plant species belonging to 3 classes, 29 families and 46 genera were distributed. Among them are useful plants like Acorus calamus L., Butomus umbellatus L., Orchis umbrosa Kar. Et Kir., Persicaria amphibia (L.) Delarb., Persicaria hydropiper (L.) Delarb., Nasturtium officinale R. Br., Urtica dioica L., Bidens tripartite L., Inula. britannica L., Tussilago farfara L., Mentha asiatica L. and others (Nurniyozov, Tashpulatov, 2019).

The following is a characteristic of the plant formations of water bodies of the Samarkand region.

The class of formations is hydrophytic or real aquatic vegetation.

A group of plant formations completely submerged in water.

Subgroup formations rooting plants.
Formation of mollusks large (Najadeta majoris)

The association of mollusks is large with aquatic plants (Najadetum majoris aqui herbosum). The association includes: Najas major ( $\left.\operatorname{cop}^{2}\right)$, Ceratophyllum demersum $\left(\operatorname{cop}^{1}\right)$, Potamogeton crispus (sp).

A subgroup of formations of non-rooting plants.

Formation of the horn leaf immersed (Ceratophylleta demersi)

The association of a robehead immersed with aquatic plants (Ceratophylletum demersi aqui-herbosum). Grass in most cases, twotier. Underwater level: Ceratophyllum demersum ( $\left.\operatorname{cop}^{2}\right)$, Ceratophyllum submersum (sp), Potamogeton crispus (sp), Potamogeton perfolatus (sp), Potamogeton lucens ( $\left.\operatorname{cop}^{1}\right)$. Flooding tier: Lemna minor (cop $\left.{ }^{1}\right)$, Potamogeton natans (sp).

A group of plant formations submerged in water with surface reproductive organs.

Subgroup formations rooting plants.

Formation of the brilliant ridge (Potamogetoneta lucentis)

Association of brillant brilliant with aquatic plants (Potamogetonetum lucentis aqui herbosum). Herbage usually two-tier. Underwater tier Potamogeton lucens $\left(\mathrm{cop}^{3}\right)$ Potamogeton perfolatus (cop $\left.{ }^{1}\right)$, Ceratophyllum demersum (cop ${ }^{1}$ ), Potamogeton crispus (sp). Surface tier: Lemna minor (cop2).

Formation of the curly ridge (Potamogetoneta crispi)

The association of the curl curst with aquatic plants (Potamogetonetum crispi aqui 
herbosum). Herbage two three-tier. Underwater layer: Potamogeton crispus $\left(\operatorname{cop}^{3}\right), \quad$ Potamogeton perfolatus (sp), Potamogeton lucens ( $\left.\mathrm{cop}^{1}\right)$, Ceratophyllum demersum ( $\operatorname{cop}^{1}$ ), Myriophyllum verticillatum (sp). Floodline: Lemna minor $\left(\mathrm{cop}^{1}\right)$. Tier of surface plants: Sagittaria sagittifolia (sp), Butomus umbellatus (sp).

\section{Formation of pierced leaf (Potamogetoneta perfoliati)}

The association of the primitolithia rdesta with aquatic plants (Potamogetonetum perfoliati aqui-herbosum).

Grass two-tier. Tier flood plants: Lemna minor $\left(\mathrm{cop}^{1}\right)$, Lemna trisulca $\left(\mathrm{cop}^{1}\right)$. Tier of underwater plants: Potamogeton perfolatus $\left(\operatorname{cop}^{3}\right), \quad$ Potamogeton lucens ( $\left.\operatorname{cop}^{1}\right)$, Myriophyllum verticillatum (sp), Potamogeton crispus (sp).

Formation of the floating pride (Potamogetoneta natantis)

The association of the river float with aquatic plants (Potamogetonetum natantis aquiherbosum). Herbage, mainly bunk. Underwater layer: Ceratophyllum demersum $\left(\mathrm{cop}^{2}\right), \quad$ Potamogeton perfolatus (sp), Potamogeton lucens (sp). Floodline: Potamogeton natans $\left(\mathrm{cop}^{2}\right)$, Lemna minor $\left(\operatorname{cop}^{1}\right)$.

\section{Formation of duckweed (Lemneta minoris).}

The association of the small duckweed with aquatic plants (Lemnetum minoris aquiherbosum). Grass two-tier. Flooded tier most often make up Lemna minor $\left(\operatorname{cop}^{3}\right)$, Potamogeton natans (sp). Tier underwater plants: Ceratophyllum demersum $\left(\operatorname{cop}^{2}\right)$, Potamogeton perfolatus $\left(\mathrm{cop}^{1}\right)$, Potamogeton crispus $\left(\operatorname{cop}^{1}\right)$.

\section{Formation class coastal aquatic vegetation}

Formation of the reed of the south (Phragmiteta australis)

Association of reed south with lake reeds (Phragmitetum australis scirposum).

In addition to Phragmites australis $\left(\mathrm{cop}^{3}\right)$ and Scirpus lacustris (cop1), the community may include Butomus umbellatus (sp) and Sagittaria sagittifolia (sp).

The association of the reed of the south with the cone-leaf-leaved (Phragmitetum australis typhosum). Herbage single tier. In addition to Phragmites australis $\left(\mathrm{cop}^{3}\right)$ and Typha angustifolia (cop1), single specimens of Sagittaria sagittifolia, Typha latifolia, Butomus umbellatus are noted.

Association of the reed of the south with the duckweed (Phragmitetum australis lemnosum). Grass two-tier. Floodline: Lemna minor (cop1), Lemna trisulca (sp). Tier of surface plants: Phragmites australis ( $\mathrm{cop}^{2}$ ), Typha angustifolia (sp), Scirpus lacustris (sp).

\section{Formation of cattail of typha (Typheta} angustifoliae)

The association of Typha angustifies with the reed lake (Typhetum angustifiliaes cirposum). Herbage one bunk. The association consists of Typha angustifolia $\left(\mathrm{cop}^{2}\right)$, Scirpus lacustris $\left(\operatorname{cop}^{1}\right)$, as well as single specimens of Butomus umbellatus, Ceratophyllum demersum.

The association of Typha angustifolia with umbellate susak (Typhetum angustifiliae butomosum). Herbage one bunk. Apart from Typha angustifolia $\left(\mathrm{cop}^{3}\right)$ and Butomus umbellatus (cop1), the association may include Sagittaria sagittifolia (sol), Sparganium erectum (sol), Lemna minor (sp). 
Formation of umbrella bridle (Butometa umbellati)

The association of the umbellate banana with aquatic plants (Butometum umbellate aqui herbosum). Grass two-tier. Floodline: Lemna minor ( $\left.\operatorname{cop}^{1}\right)$.

Surface tier: Butomus umbellatus $\left(\mathrm{cop}^{2}\right)$, Phragmites australis (sp), Scirpus lacustris (sp), Sagittaria sagittifolia (sp).

Formation of the marine tubercle (Bolboschoeneta maritimae)

The association of sea klubnekamish with aquatic plants (Bolboschoenetum maritime aqui-herbosum). The association includes: Bolboschoenus maritimus $\left(\mathrm{cop}^{2}\right)$, Sparganium erectum ( $\left.\operatorname{cop}^{1}\right)$, Butomus umbellatus (sp), Typha angustifolia $\left(\operatorname{cop}^{1}\right)$.

Formation of a part of the plantain (Alismeta plantago-aquaticae)

The association of the common plant with water plants (Alismetum plantago aquatic aqui-herbosum).

Herbage single tier. In addition to Alisma plantago-aquatica $\left(\mathrm{cop}^{2}\right)$, the association may include Sparganium erectum (sp), Butomus umbellatus (sp), Sium latifolium (sp).

Formation of lake reeds (Scirpeta lacustris).

Association of lake reeds with aquatic plants (Scirpetum lacustris aqui herbosum). Twolevel grass, less often three-tier. The surface tier includes: Scirpus lacustris $\left(\mathrm{cop}^{2}\right)$, Butomus umbellatus (sp), Sagittaria sagittifolia (sp), Typha angustifolia (sp). Lemna minor (cop1) make up the flood tier. Ceratophyllum demersum occasionally forms an underwater layer.
Formation of arrowhead arrow (Sagittarieta sagittifoliae)

The association of arrowheads with arrowheads with aquatic plants (Sagittarietum sagittifoliae aqui-herbosum). Herbage two three-tier. Surface tier: Sagittaria sagittifolia $\left(\mathrm{cop}^{2}\right)$, Butomus umbellatus (sp), Sparganium erectum (sp), Alisma plantago-aquatica (sp), Scirpus lacustris (sp). The flood tier may include Lemna minor $\left(\operatorname{cop}^{1}\right)$ or Lemna trisulca $\left(\operatorname{cop}^{1}\right), \quad$ Salvinia natans (sp). Underwater layer: Ceratophyllum demersum $\left(\operatorname{cop}^{1}\right), \quad$ Potamogeton crispus (sp), Potamogeton perfolatus (sp).

Formation of the headrest (Sparganieta erecti)

The association of the headrest straight with aquatic plants (Sparganietum erecti aquiherbosum). Two-tier grass stand. Tier of underwater plants: Potamogeton lucens (cop2), Potamogeton crispus (cop1), Potamogeton perfolatus (cop1), Ceratophyllum demersus (sp). Floodline: Lemna minor (cop1). Surface tier: Sparganium erectum (cop2), Scirpus lacustris (cop1), Butomus umbellatus (sp), Sagittaria sagittifolia (sp), Persicaria amphibia (sp).

Thus, in the vegetation cover of different types of water bodies of the Samarkand region, 15 formations were identified, which unite 18 associations. Community vegetation is characterized by poverty of species composition and relative simplicity of structure.

\section{References}

Gopal B. 2009. Biodiversity in Wetlands // Maltby E., Barker T. (eds.) The Wetlands Handbook, 2 Volume Set. Chichester, UK, Hoboken, NJ; WileyBlackwell. P. 65-95. 
Kadlec R.H. and Wallace S.D. 2009. Treatments wetlands. 2nd ed. Boca Raton; London; New York, CRC Press Taylor and Francis Group. 1000 p.

Kirichenko K.A. 2015. Vozmojnosti ispolzovaniya vysshix-vodnyx rastenie dlya biomonitoringa ekologicheskogo sostoyaniya vodoyomov Baikalskogo regiona [Possibilities of using higheraquatic plants for biomonitoring the ecological state of water bodies of the Baikal region] // pp 133-136. Hydrobotany 2015. Proceedings of the VII All-Russian Conference with international participation on water macrophytes. Borok,

Kirilyuk V.E., Obyazov V.A., Tkachuk T.E. and Kirilyuk O.K. 2012. Influence of Climate Change on Vegetation and Wildlife in the Daurian Eco-region // Eurasian Steppes. Ecological Problems and Livelihoods in a Changing World. Dordrecht; Heidelberg; New York; London, Springer. P. 397-424.

Kirilyuk V.E., Tkachuk T.E., Kirilyuk O.K. 2012. Vliyanie izmeneniy klimata na mestoobitaniya I biotu b Daurii [Impact of climate change on habitats and biota in Dauria] // pp 46-62. Environmental and water management aspects. Collection of scientific papers of the State Natural Biosphere Reserve. "Daursky". Chita, Express Publishing. Release 5.

Laktionov A.P., Meshcheryakova N.O., Pilipenko V.N. 2014. Flora vodoyomov I vodotokov Astraxanskiy oblasti [Flora of reservoirs and watercourses of the Astrakhan region]; pp. 407. Astrakhan.
Lisitsyna L.I. 2003. Gerbarizasiya vodniy rasteniy, oformlenie kolleksiy [Herbarization of aquatic plants, decoration collections]; pp. 49-55 // Hydrobotics: methodology, methods: School materials on hydrobotany. Rybin.

Metody polevyx ekologicheskix issledovaniy 2014. Otv. Redactor A.B. Ruchin. [Field Ecological Research Methods]; pp. 407. Textbook, Saransk; Pushta

Nurniyozov A.A., Tashpulatov Y.Sh. 2019. Poleznye vodnye i pribrejnye rasteniya Samarkandkoy oblasti (Uzbekistan) [Useful aquatic and coastal plants of the Samarkand region (Uzbekistan)]; pp. 85-88. // Bulletin of science. - Tolyatti, № 6 .

Oprediletel rasteniy Sredney Azii. 1968. [Key to Central Asian plants]; pp. 225 // Tashkent, Volume I.

Papchenkov V.G. 2003. O klassifikasii rasteniy vodoemov I vodotokov [On the classification of plants of water bodies and streams] pp 23-26 // Hydrobotany: methodologies and methods. Materials school on hydrobotany. Borok.

Scherbakov A.B. 2015. Izucheniya vodnyx flory Sredney Rossii na sovremennom etape, yyo dinamika I perspektivy dalneyshego izuchenie [The study of aquatic flora of Central Russia at the present stage, its dynamics and prospects for further study] // pp. 60-62. Hydrobotany 2015. Proceedings of the VII All-Russian Conference with international participation on water macrophytes. Borok.

\section{How to cite this article:}

Tashpulatov, Y.Sh., I.Kh. Khamdamov and Nurniyozov, A.A. 2019. Water and Coastal Water Vegetation of Various Types of Waters in the Samarkand Region. Int.J.Curr.Microbiol.App.Sci. 8(08): 922-928. doi: https://doi.org/10.20546/ijcmas.2019.808.106 